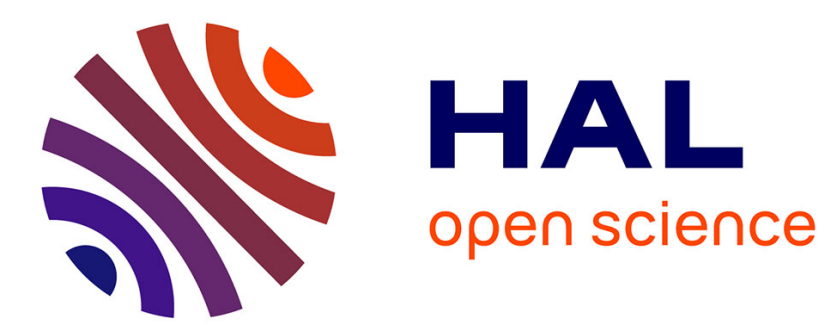

\title{
EBIC AND DLTS MEASUREMENTS OF SI-AND POLYCRYSTALLINE SILICON
}

\author{
A. Bary, J. Hamet, A. Ihlal, J. Chermant, G. Nouet
}

\section{To cite this version:}

A. Bary, J. Hamet, A. Ihlal, J. Chermant, G. Nouet. EBIC AND DLTS MEASUREMENTS OF SI-AND POLYCRYSTALLINE SILICON. Journal de Physique Colloques, 1988, 49 (C5), pp.C5-665-

C5-670. 10.1051/jphyscol:1988586 . jpa-00228083

\section{HAL Id: jpa-00228083 https://hal.science/jpa-00228083}

Submitted on 1 Jan 1988

HAL is a multi-disciplinary open access archive for the deposit and dissemination of scientific research documents, whether they are published or not. The documents may come from teaching and research institutions in France or abroad, or from public or private research centers.
L'archive ouverte pluridisciplinaire HAL, est destinée au dépôt et à la diffusion de documents scientifiques de niveau recherche, publiés ou non, émanant des établissements d'enseignement et de recherche français ou étrangers, des laboratoires publics ou privés. 
Résumé - L'irfluence des joints de grains sur les propriétés électro-

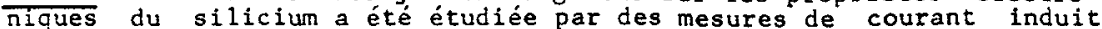
(EBIC), de capacité thermiquement activée (TSCAP) et de spectroscopie capacitive des niveaux profonds (DLTS). Ainsi des sous-joints issus de plaques polycristallines destinées à la fabrication de cellules solaires ont été examinés en EBIC à l'état brut de solidification et après le traitement de diffusion de la jonction. Nos résultats montrent que la longueur de diffusion locale et la vitesse de recombinaison des porteurs minoritaires sont diminuées par ce traitement. Les méthodes TSCAP et DLTS ont étè appliquées à un joint de grains ayant l'orientation de coincidence $\Sigma 13$. Ces mesures ont été effectuées après diffusion d'or dans un bicristal et recuit d'homogénéisation, et sur un bicristal n'ayant subi que le recuit d'homogénétsation pour comparer 1 'effet du traitement thermique. Le recult fait apparaitre un continuum d'états d'interface peu étendu qui n'apparaft pas après diffusion d'or. Dans ce cas on ne détecte plus d'états d'interface, mais un niveau piège situé au voisinage du joint ( 0 $0,5 \mu \mathrm{m})$ qui est le niveau donneur de l'or. Cette diffusion de phosphore ou d'or peut être interprétée comme une passivation des joints de grains.

Abstract - Influence of grain boundaries on the electronic properties of silicon has been studied by electron-beam induced current (EBIC), thermally stimulated capacitance (TSCAP) and deep-level transient spectroscopy (DLTS). Low-angle grain boundarles taken from as-grown polycrystalline wafers for solar cells have been analyzed by EBIC and their behaviors have been compared after the junction diffusion treatment. This treatment gives a decrease of the local diffusion length and recombination velocity of the minority carriers. TSCAP and DLTS methods have been applied to a coincidence orientation grain boundary $\Sigma 13$. These measurements have been made on a gold diffused bicrystal which was homogenized by annealing. These results are then compared with those of a bicrystal without gold diffusion but with the same thermal treatment. After annealing a narrow interface state continuum appears. On the contrary the gold diffusion prevents the formation of this continuum and only the donor level of gold is detected in the space charge region of the grain boundary ( $0-0.5 \mu \mathrm{m})$. This diffusion of phosphorus or gold can be interpreted as a grain boundary passivation.

\section{1 - INTRODUCTION}

In polycrystalline seniconductors the mobility of the electrical carriers is modified by the geometrical defects such as high-angle grain boundaries, low-angle grain boundaries, dislocations... ( $(1,2)$. So it is of interest to have a best understanding of this phenomenon. Both suitable methods to inspect the mobility of the electrical carriers are the measurements of the induced current by the electron beam of a scanning electron microscope (EBIC) and the determination of the variation of the 
capacitance related to the electrostatic charge of the grain boundary (TSCAP, DLTS). The first method gives access to some parameters characteristic of the minority carriers whereas the capacitance methods concern the majority carriers.

A lot of results have been obtained by combined analysis TEM-EBIC. However most of them deal with high angle grain boundaries and the results are rather qualitative (3-6). The DLTS method has previously been limited to the determination of the deep traps located in the gap of the bulk (7). Recently this method has been adapted to determine the energy levels related to low angle and high angle grain boundaries (810).

In polycrystalline solar cells these geometric defects can give rise to potential bartiers and a decrease of the photovoltaic yield will occur (11). However the mutual interaction between the elements segregated and geometric defects can be responsible for the improvement of the solar cell properties. Therefore we aim at determining the major parameters of this modification by analyzing separately low angle grain boundaries taken from polycrystalline wafers Polix, grown by Photowatt Int, and high angle grain boundaries intentionally grown by LETI-CENG.

\section{2 - MATERIALS AND TECHNIQUES}

Polix material is characterized by large grains including many low angle grain boundaries. This morphology is obtained by unidirectional solidification with a monitored cooling of the cructble bottom. The final structure of the ingot is typicalfy columnar $(12-13)$. The wafers are boron $p$-type, the doping range is $10^{16} \mathrm{~cm}^{-3}$.

High angle grain boundaries are in fact bicrystals with a coincidence orientation and a symmetric boundary. For these experiments we have only studied the orientation $\Sigma$ 13. The rotation angle is $22^{\circ} 62$ around $\langle 001\rangle$ axis and the bqundary plane $\{510\}$. This bicrystal is also p-type but the doping range is $7.10^{14} \mathrm{~cm}^{-3}$.

EBIC investigations were carried out in a scanning electron microscope operating at $30 \mathrm{kV}$. In order to control the effects of the junction diffusion treatment, $\left(850^{\circ} \mathrm{C}\right.$, $30 \mathrm{mn}, \mathrm{POCl}_{3}$ ), similar boundaries cut out of adjacent as-grown wafers, $400 \mu \mathrm{m}$ apart, were analyzed with Schottky barriers. The rectifying contact was obtained by vacuum deposition of chromium, thickness of $30 \mathrm{~nm}$ on the polished surface of the as-grown wafer. An alloy Al-Ga was cold-deposited on the back surface to give an ohmic contact. Micrographs allow a qualitative estimation whereas a storage in a computer allows a quantitative analysis by Donolato's model as we shall see later. The intensity of the incident electron beam is measured by a Faraday cage.

For capacitance measurements the specimen is a parallelepiped $\left(15 \times 2,5 \times 2,5 \mathrm{~mm}^{3}\right)$ with the boundary plane parallel to the smallest surfaces. Two ohmic contacts are made on these external surfaces. The measurements take place in the temperature range $77 \mathrm{~K}$ $300 \mathrm{~K}$. To: examine the effects of segregation of gold upon the properties of the grain boundary a thin layer of gold was deposited by evaporation onto only one surface. This layer was then diffused at $900^{\circ} \mathrm{C}$ for $30 \mathrm{~min}$ in argon. After removal of the gold excess by etching in a $\mathrm{HNO}_{3}-\mathrm{HCl}$ mixture, the specimen was placed horizonta$11 y$ on a flat quartz boat and finally annealed at $900^{\circ} \mathrm{C}$ for 4 days and cooled by quenching. A similar thermal treatment was carried out on an another bicrystal to determine whether the properties of the grain boundary was dependent upon the gold diffusion or thermal treatment.

\section{3 - METHODS}

\section{3-1 EBIC mode}

The scanning of the surface of a semiconductor by an electron beam with an energy in the range 1 to $50 \mathrm{keV}$ is the simplest technique for producing hole-electron pairs 
and examinating theit recombination at the grain boundaries (14-15). The effective carriers are the minority carriers, electrons in p-type semiconductor. The current collected in an external circuit is due to the diffusion of these carriers towards the $p-n$ junction or Schottky barrier. The recombination of these pairs on defects such as grain boundaries results in a lower current and a darker contrast is obtained on the micrographs. The quantitative interpretation of the contrast has been modelled by different authors (16-17). Donolato has proposed a calculation of the diffusion length and recombination velocity by using a statistical approach (18).

\section{3-2 Capacitance methods}

In the TSCAP method the capacitance of the bicrystal is measured versus temperature by applying a constant bias voltage (19). For different values of the applied voltage $V=V_{1}-V_{2}$, the capacitance and charge of the bicrystal are determined.

A constant bias voltage is applied during the temperature decrease so that electrical charges are trapped at the interface. At $77 \mathrm{~K}$ the emisstion rate is very low. When the temperature increases by a zero biasing, these charges are released and a modification of the interface charge happens. An abrupt relaxation is characteristic of a discrete state whereas a progressive relaxation is due to an interface state continuum. Consequently the relaxation to the equilibrium deduced from the shape of the curves $C=f(T)$ gives information about the interface state density. This method is rather qualiftetive and more precise results need to use the DLTS method.

To characterize the traps present in the bulk of a semiconductor LANG ( 7 ) developed a new method (DLTS) to analyze the capacitance transients. The extension of this method to MIS structures (20) and grain boundaries ( $8-10)$ has been performed. In this case the interface states are filled by bias voltage pulses and between two pulses, the charge of the grain boundaries relaxes to the equilibrium by thermal emission of the trapped charges. Thus the charge relaxation is detected by the variation of the grain boundary capacitance. The grain boundary charge is related to the capacitance by the following equation : $Q=q N_{d} \varepsilon / C$

\section{4 - RESULTS}

\section{4-1 EBIC}

Two typical EBIC images are shown in figure 1. Figures la and lb correspond to the
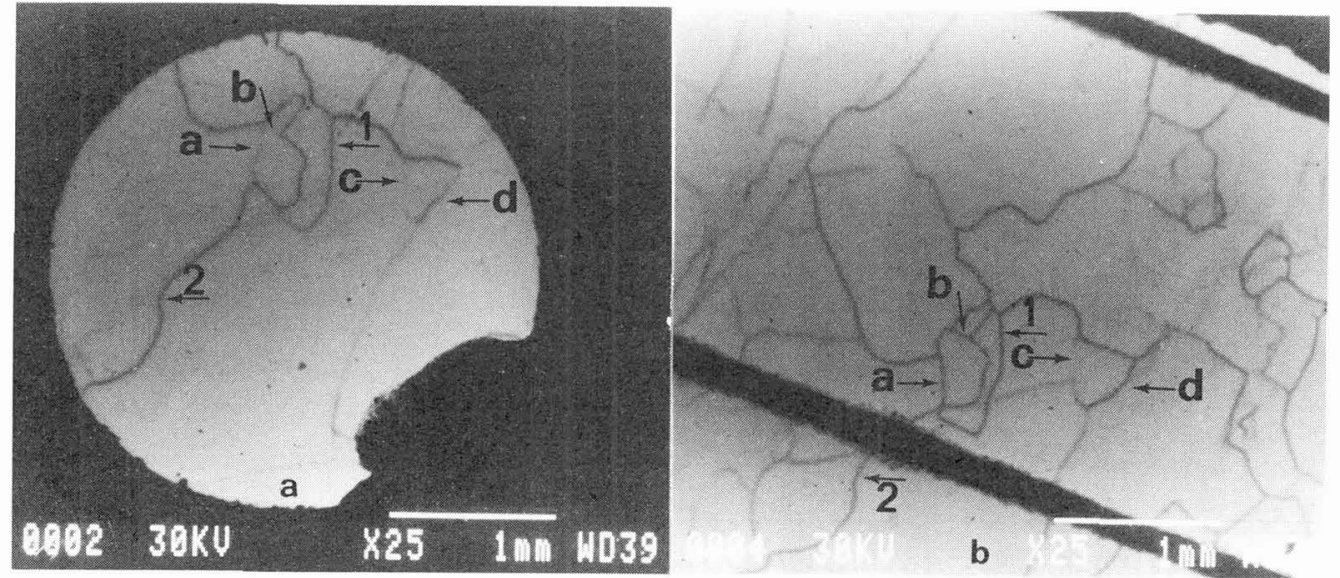

Fig. I : EBIC micrographs of low angle grain boundaries; Schottky barrier, as-grown material (a) ; p-n junction, diffused material (b). 
Schottky barrfer and $p-n$ junction respectively. The contrasts of some lowmangle grain boundaries marked $a, b, c, d \ldots$ are not similar and an enhancement of this contrast is observed in the $p-n$ junction. Thus two quantitative analysis have been carried out on the interfaces marked 1 and 2. The two profiles are given in the figure 2 and the values of the contrast, $C, C=I / I$ ( $I$ current value at the defect, I constant background current), diffusion length, $L$, and recombination velocity, ${ }_{v}$, in table 1 . These two last parameters were calculated from Donolato's model.

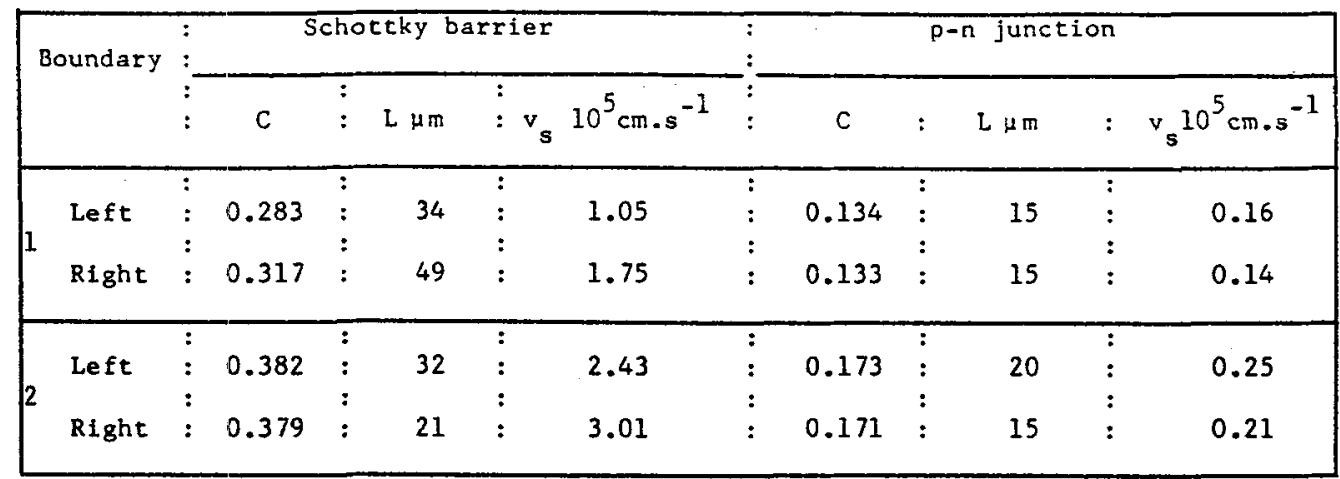

Table 1 : Contrast, $C$, diffusion length, $L$, and recombination velocity, $v$, for two low-angle grain boundarles, as-grown (Schottky barrier) and $\mathrm{POCl}_{3}$ diffúsed ( $p-n$ junction).

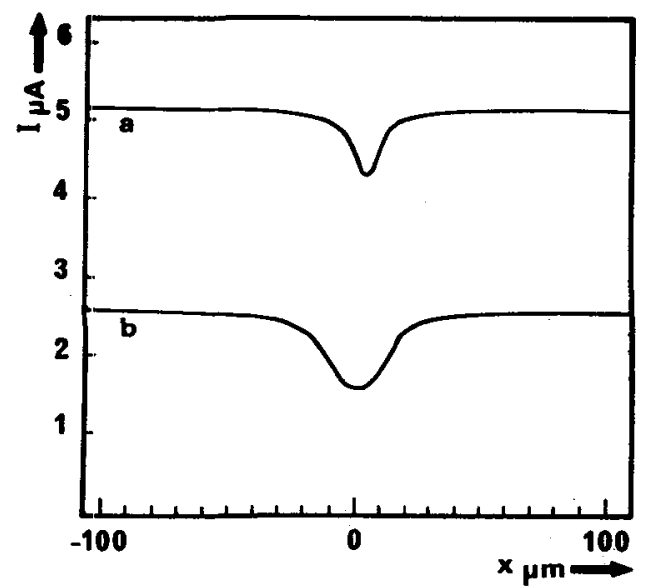

Fig. 2 : EBIC profiles of the low-angle grain boundary 2. a : p-n junction, b: Schottky barrier.

The diffusion length is measured in the vicinity of the boundary, about $100 \mu \mathrm{m}$.

As for the recombination velocity its reduction means an enhancenent of the quality or passivation of the low angle grain boundary. 


\section{4-2 TSCAP and DLTS experiments}

The curves $C=f(T)$ of the annealed bicrystal $\left(900^{\circ} \mathrm{C}, 4\right.$ days, Ar) show a spread relaxation which is characteristic of an interface state continuum (Fig. 3 ). The emission of holes takes place progressively with the temperature rise. For the same specimen the DLTS peaks shift as the pulse varies which is also typical of an interface state continuum (Fig. 4).

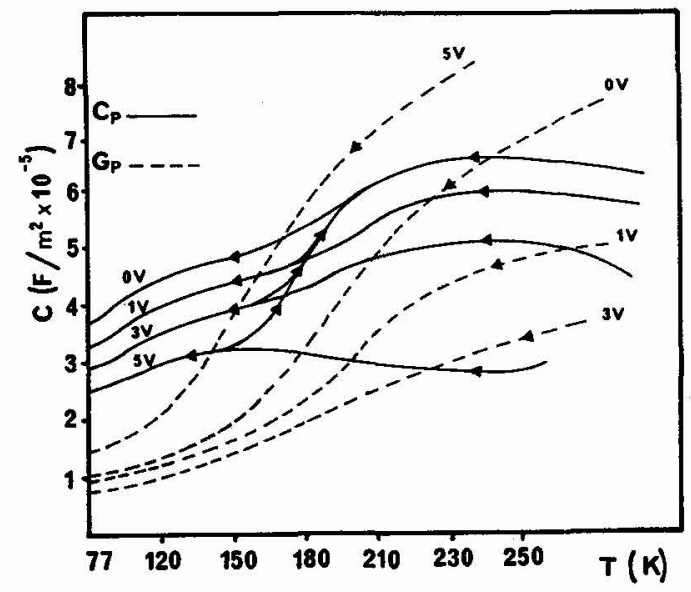

Fig. 3 : ISCAP plot of the annealed bicrystal for different pulses showing a spread relaxation.

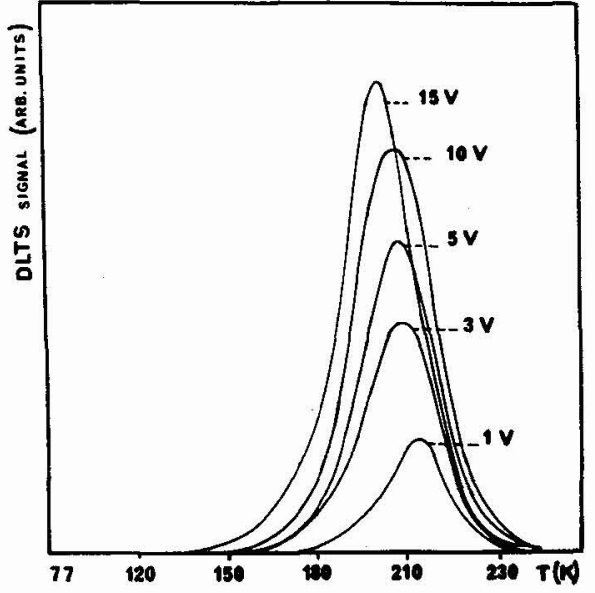

Fig. 4 : Shift of DLTS peaks by varying the pulse. Annealed bicrystal $\left(900^{\circ} \mathrm{C}, 4\right.$ days, Ar).

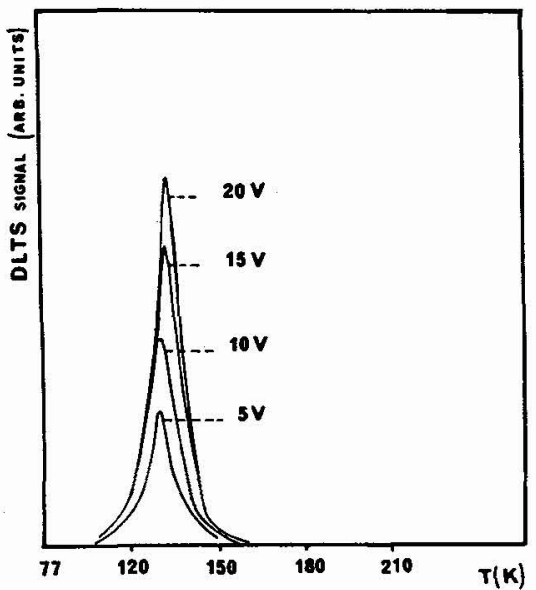

Fig. 5 : No shift of DLTS peaks varying the pulse. Bicrystal containing gold + annealed $\left(900^{\circ} \mathrm{C}, 4\right.$ days, $\left.\mathrm{Ar}\right)$. 
On the contrary, the DLTS peaks of the specimen containing gold are not sensitive to the variation of the voltage pulses (Fig. 5). The light displacement is likely due to the instability of the temperature. So, these peaks correspond to a discrete level with an energy of $0.345 \mathrm{eV}$ above the valence band. The emission cross section

$\sigma$ is about $6.10^{-16} \mathrm{~cm}^{2}$. This level can be attributed to the donor level of gold in bulk silicon. Consequently no interface state was detected on the silicon bicrystal after gold diffusion and annealing. The interface state continuum found in the silicon bicrystal only annealed has not been detected anymore and a passivation of the grain boundary can be supposed.

\section{CONCLUSION}

In this paper we have provided experimental evidence that phosphorus and gold diffum sion have beneficial effects by passivation of low-angle or high-angle grain boundaries. Further experiments are needed to precise and clarify these behaviors with regard to the type of low-angle grain boundaries and coincidence or near-coincidence structure of high-angle grain boundaries.

\section{ACKNOWLEDGMENTS}

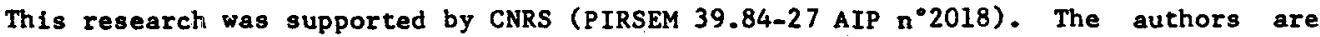
indebted to Broniatowski $A$. for helping with the DLTS measurements and fruitfull discussion. They also thank Photowat Int. for providing the Polix wafers and $M$. AUBERT (LETI-CEN Grenoble) for the synthetic silicon bicrystals.

\section{REFERENCES}

1. Grovenor, C.R.M., J. Phys. C. : Solid State Phys. 18 (1985) 4079.

2. Mataré, H.F., J. Appl. Phys. 59 (1986) 97.

3. Diantei11, C. and Rocher, A., J. Phys. $43 \mathrm{Cl}$ (1982) 75.

4. Ast, D.G., Cunningham, B. and Gleichman, R., "Grain Boundaries in Serniconductors" Ed. H.J. Leamy, G.E. Pike and C.H. Seager (1982) p.85 (New York-North Holland).

5. Maurice, J.L. and Laval, J.Y., J. Phys. $43 \mathrm{Cl}$ (1982) 207.

6. Ruterana, P., Bary, A. and Nouet, G., J. Phys. $43 \mathrm{Cl}$ (1982) 27.

7. Lang, D.V., J. Appl. Phys. 45 (1974) 3023.

8. Broniatowski, A., J. Phys. $43 \mathrm{Cl}$ (1982) 63.

9. Broniatowski, A. and Bourgoin, J.C., "Grain Boundaries in Semicoonductors" Ed. H.J. Leany, G.E. PIke and C.H. Seager (1982) p. 119 (New York-North Holland).

10. Broniatowski, A., Thesis, University of Paris (1984).

11. Poullain, G., Mercey, B. and Nouet, G., J. Appl. Phys. 61 (1987) 1547.

12. Lay, P., Thesis, University of Caen (1987).

13. Lay, P., Chermant, J.L. and Nouet, G., Rev. Phys. App1. 22 (1987).

14. Hanoka, J.I. and Bel1, R.O., Ann. Rev. Mat. 11 (1981) 353.

15. Leamy, H.J., J. Appl. Phys. 53 (1982) R51.

16. Zook, J.D., Appl. Phys. Lett. 37 (1980) 223.

17. Marek, J., J. Appl. Phys. 53 (1982) 1454.

18. Donolato, C., J. Appl. Phys. 54 (1983) 1314.

19. Mueller, R.K., J. Appl. Phys. 30 (1959) 546.

20. Yamasaki, K., Yoshida, M. and Sugano, I., Jap. J. Appl. Phys. 18 (1979) 11.3. 